\title{
Sensitivity and specificity of serum procalcitonin level compared to leucocyte count for diagnosis of surgical site infection on patients undergoing major surgery
}

\author{
Muhammad Sayuti $^{1 *}$, Supomo ${ }^{2}$, Umi Sholekah Intansari ${ }^{3}$ \\ 'Study Program of Medical Doctor, Universitas Malikussaleh, Aceh, ${ }^{2}$ Sub Division of \\ Thorax Cardiovascular, Department of Surgery, ${ }^{3}$ Department of Clinical Pathology, \\ Faculty of Medicine, Universitas Gadjah Mada/Dr. Sardjito General Hospital, Yogyakarta, \\ Indonesia
}

\begin{abstract}
Surgical site infection (SSI) is one of the most serious complications on sugical procedure. However, its diagnosis is still based on the clinical and laboratory examination that take more time and less sensitive and specific. Therefore, early diagnosis that is more accurate and precise is needed. Some biomarker such as serum procalcitonin (PCT) is promoted for diagnosis SSI. The aim of the study was to evaluate the sensitivity and specificity of serum PCT compared with leucocyte for diagnosis of SSI on patients undergoing major surgery. This was a descriptive analytical study with a prospective observational design. Patients who underwent a major surgery between October $30^{\text {th }}$ and December $31^{\text {st }}, 2011$ and fulfilled the inclusion and exclusion criteria were recruited. Clinical and laboratory examinations including leucocyte count were conducted presurgery. On $3^{\text {rd }}$ day postsurgery, blood sample was taken for PCT and leucocyte count measurement. A blood bacterial culture was performed on patients suffering from SSI according to Centers for Disease Control (CDC) criteria. Patients were then followed until 30 days postsurgery. A total of 49 patients consisting of 22 men and 27 women were involved in this study. Surgical site infection was found in 16 patients consisting of $8(50 \%)$ patients with clean surgical wound, $3(19 \%)$ patients with clean surgical contamination wound, $4(25 \%)$ patients with surgical contamination wound and $1(6 \%)$ patient with dirty surgical wound. Furthermore, laboratory examination found that 9 patients had abnormal leucocyte with 6 of them suffering from SSI, whereas from 15 patients with serum PCT abnormal, and 11 patients suffered from SSI. Diagnostic test showed that the sensitivity and specificity of serum PCT for diagnosis of SSI were 68.75 and $90.90 \%$, respectively, whereas the sensitivity and specificity of leucocyte were 31.25 and $87.87 \%$, respectively. In conclusion, serum PCT has better sensitivity and specificity compared with leucocyte for the diagnosis of SSI in patients with major surgery.
\end{abstract}

\section{ABSTRAK}

Infeksi luka operasi (ILO) merupakan salah satu komplikasi paling serius pada pembedahan. Namun demikian, diagnosis ILO masih bedasarkan pemeriksaan klinik dan laboratorium yang butuh waktu lama dan kurang sensitif maupun spesifik. Oleh karena itu, diagnosis dini yang lebih akurat dan tepat diperlukan. Beberapa biomarker seperti kadar prokalsitonin (PCT) dipromosikan untuk diagnosis SSI. Penelitian ini bertujuan untuk mengkaji sensitivitas dan spesifisitas PCT serum dibandingkan leukosit untuk diagnosis ILO pada pasien yang menjalani bedah mayor. Penelitian ini merupakan penelitian deskriptif analitik dengan rancangan observasional prospektif. Pasien yang menjalani bedah mayor antara 30 Oktober dan 31 Desember 2011 dan memenuhi kriteria inklusi dan eksklusi dilibatkan dalam penelitian. Hari ke 3 setelah

\footnotetext{
* corresponding author: say_md@yahoo.com
} 


\begin{abstract}
pembedahan, sampel darah diambil untuk pemeriksaan kadar PCT dan leukosit. Pasien yang mengalami ILO menurut kriteria Centers for Disease Control (CDC), dilakukan kultur bakteri darah. Selanjutnya pasien diikuti kondisinya hingga 30 hari setelah pembedahan. Sebanyak 49 pasien terdiri dari 22 laki-laki dan 27 perempuan terlibat dalam penelitian. Infeksi luka operasi ditemukan pada 16 pasien yang terdiri dari 8 (50\%) pasien denga luka operasi bersih, 3 (19\%) pasien dengan luka operasi bersih kontaminasi, 4 (25\%) pasien dengan luka operasi kontaminasi dan $1(6 \%)$ pasien dengan luka operasi kotor. Pada pemeriksaan laboratorium ditemukan 9 pasien mempunyai leukosit abnormal dengan 6 diantaranya mengalami ILO, sedangkan diantara 15 pasien dengan PCT serum abnormal, 11 pasien mengalami ILO. Tes diagnosis menunjukkan sensitivitas dan spesifitas PCT serum untuk diagnsosi ILO berturut-turut adalah 68,75 dan 90,90\%. Sedangkan sensitivitas dan spesifitas leukosit berturut-turut adalah 31,25 dan 87,87\%. Dapat disimpulkan bahwa PCT serum mempunyai sensitivitas dan spesifitas lebih baik dibandingkan leukosit untuk diagnosis ILO pasien bedah mayor.
\end{abstract}

Keywords: procalcitonin serum - leucocyte - surgical site infection - diagnostic test - sensitivity - specificity

\section{INTRODUCTION}

Infection handling and prevention are now improving with an effective antibiotic discovery, complete immunization and modern sanitation. However, infection remains the most common cause of morbidity and mortality rate in many health care services in the world. ${ }^{1} \mathrm{~A}$ prevalence survey conducted in 55 hospitals of 14 countries representing 4 WHO Regions namely Europe, Eastern Mediterranean, SouthEast Asia and Western Pacific showed that an average of $8.7 \%$ of hospital patients had nosocomial infections. At any time, over 1.4 million people worldwide suffer from infectious complications acquired in hospital. ${ }^{2}$ Even in the developed countries where the medical services are well-developed, infection is also proclaimed as the highest cause of serious disease. ${ }^{1}$ In USA, the Centers for Disease Control and Prevention (CDC) estimate roughly 1.7 million hospital-associated infections, from all types of bacteria combined, causing 99,000 deaths annually. ${ }^{3}$

One of the most often serious complications in surgical procedure is surgical site infection. Surgical site infection (SSI) is defined as the presence of liquid pus, abscess or cellulitis which extends on a wound within 30 days after surgery or within 1 year in case of implant. ${ }^{4,5}$ Surgical site infection is diagnosed with clinical and laboratory examination. The diagnosis begins with an inspection to check any pus, abscess, inflammation reaction or cellulitis that extends on the surgical site. An open wound is also being checked, as well as pus liquid or abscess that leaks from organ or cavum. Pus or tissue specimen should be taken for culture examination and routine blood count for leucocyte count should be investigated. ${ }^{4}$

Procalcitonin (PCT) and leucocyte count are indicators of systemic infection. Procalcitonin is one of the applicable markers to detect bacterial infection in children and adults. ${ }^{6}$ Plasma PCT level is comparable with specific response of bacterial infection, particularly for invasive or probably-invasive bacteria. High concentration of PCT indicates sepsis, severe sepsis or even septic shock condition. It may also represent another possibility and gives additional information towards conventional clinical data. Some studies state that procalcitonin is better, or at least has the same diagnosis potency with another infection marker such as CRP, leucocytosis and fever. ${ }^{7}$

A study conducted in a Pediatric Intensive Care Unit, Guy's Hospital, London shows that PCT level is better to be used as diagnostic marker than the leucocyte count in a critical patient. A procalcitonin concentration of $2 \mathrm{ng} /$ 
$\mathrm{mL}$ might be useful in differentiating severe bacterial disease in infants and children. ${ }^{6}$ Another study conducted in Department of Anesthesiology and Critical Care, and Department of Pharmacy, Military Hospital, Tunis University, Tunis to compare the accuracy of PCT to diagnose postoperative infection after cardiac surgery and compare it with those of C-reactive protein, white blood cell count, and interleukins 6 and 8 concluded that PCT is a valuable marker of bacterial infections after cardiac surgery. ${ }^{8}$

This study was conducted to evaluate the sensitivity of PCT compared to leucocyte count in the diagnosis of bacterial infection after surgery in patients who underwent major surgery at Dr. Sardjito General Hospital, Yogyakarta.

\section{MATERIALS AND METHODS}

\section{Subjects}

This was a descriptive analytical study with a prospective observational design. Patient was observed since undergoing a major surgery until 30 days postsurgery. Samples were obtained by consecutive sampling technique with a maximum sample of 50 patients. Subjects in this study were surgical patients in Dr. Sardjito General Hospital Yogyakarta who underwent major surgery between October $30^{\text {th }}$ and Desember $31^{\text {st }} 2011$.

The inclusion criteria were the patient who underwent major surgery, was more than 18 years old, and willing to participate the study by signing an informed consent. Major surgeries included in this study were cranitotomy, laminectomy, laparotomy, cholecystectomy, thoracotomy, cardiac surgery, costae clipping, mastectomy, soft tissue tumor surgery, cavum oris tumor surgery, ORIF (open reduction internal fixation), extremity amputation, open prostatectomy, orchidectomy/orchidopexy, ureterolithotomy, and pyelolithotomy. Exclusion criteria in this study were those who had been diagnosed by infection clinically before undergoing surgery, those who had major surgery due to trauma, pancreatitis, combustion or chemical substance exposure, and those who had kidney failure, HIV/AIDS, or in immunocompromised state. The study has been approved by the Health Research Ethics Committee of the Faculty of Medicine, Universitas Gadjah Mada, Yogyakarta.

\section{Experimental procedures}

On admission to Department of Surgery to undergo major surgery, clinical examinations were conducted before surgery and blood samples were taken for routine laboratory investigations including leucocyte count. An explanation concerning the background, objectives, benefits of the study was informed. Patients who fulfilled the inclusion and exclusion criteria were given an informed consent to be signed. After major surgery, SSI of patients was observed. Surgical site infection was defined as the presence of pus liquid, abscess or cellulitis that extends on the surgical site within 30 days post surgery or 1 year in case of implant according to CDC criteria. Furthermore, blood samples were then taken again for routine laboratory investigations including leucocyte counts and for PCT measurement as well as blood culture. Leucocyte counts were measured by the hospital haematology laboratory. Leucocyte count value of $4.800-10.800 / \mathrm{mm}^{3}$ was considered as normal value. Serum PCT level was measured by immunoluminometric assay (BRAHMS Diagnostika). Serum PCT level of $<0.5 \mathrm{ng} / \mathrm{mL}$ was considered as normal value. Blood culture was conducted in an aerobic and anaerobic condition using BACTEC (Becton Dickinson Diagnostic Instrument Systems, Sparks, MD, USA) 9240 automatic blood culture analyzer system.

\section{Statistical analysis}

Bivariate analysis using Chi-square $\left(\chi^{2}\right)$ was used to evaluate the relationship between leucocyte counts or PCT and SSI. Odds ratio 
(OR) with $95 \%$ confidence intervals $(95 \% \mathrm{CI})$ was calculated to assess the risk factors of SSI due to leucocyte count or PCT. A p value of less than 0.05 was considered to be significant.

\section{RESULTS}

During a period from October $30^{\text {th }}$ until December $31^{\text {st }} 2011,51$ patients who fulfilled inclusion and exclusion criteria were obtained. However, two patients could not continue this study due to loss of laboratory data. Therefore, only 49 patients could finish this study. The ages of subjects were between 22 until 77 years old with an average of 48.2 years old. Among 49 patients involved in this study, 16 patients suffered from SSI. The characteristics of patients are presented in TABLE 1, whereas the characteristics of patients suffering from SSI are presented in TABLE 2.

TABLE 1. Characteristics of patients

\begin{tabular}{lc}
\hline Characteristics & $\mathrm{n}(\%)$ \\
\hline Gender & $22(44.8)$ \\
- Male & $27(55.1)$ \\
- Female & \\
Surgery subdevision & $6(12)$ \\
- Plastic & $6(12)$ \\
- Urologic & $11(23)$ \\
- Oncologic & $17(35)$ \\
- Digestive & $4(8)$ \\
- Neurologic & $3(6)$ \\
- Thoracis & $2(4)$ \\
- Orthopedic & \\
Surgical wound & $23(47)$ \\
- Clean surgical & $17(35)$ \\
- Clean surgical & \\
- Sontamination wound & $7(14)$ \\
- Wound & \\
Surgical contamination & $2(4)$ \\
- Yes surgical wound & $16(33)$ \\
- No infection & $33(67)$ \\
\hline
\end{tabular}

TABLE 2. Characteristics of patients suffering from SSI

\begin{tabular}{lc}
\hline Characteristics & $\mathrm{n}(\%)$ \\
\hline Age (years) & $1(6)$ \\
- 21-40 years & $12(75)$ \\
- 41-60 years & $3(19)$ \\
- $>60$ years & \\
Gender & $5(31)$ \\
- Male & $11(68)$ \\
- Female & \\
Surgical wound & $8(50)$ \\
- Clean surgical & $3(19)$ \\
- Clean surgical & contamination wound \\
- Surgical contamination & $4(25)$ \\
- Dound & $1(6)$ \\
\hline
\end{tabular}

Note: SSI=surgical site infection

Clinical manisfestation of patients suffering from SSI according to CDC criteria is presented in TABLE 3. Among 16 patients suffering from SSI, 7 patients $(43.7 \%)$ had a

TABLE 3. Clinical manisfestation of patients suffering SSI according to CDC critetia

\begin{tabular}{lc}
\hline Characteristics & $\mathrm{n}(\%)$ \\
\hline Skin redness & $13(81)$ \\
- Yes & $3(19)$ \\
- No & $12(75)$ \\
Pain on the surgical site & $4(25)$ \\
- Yes & \\
Liquid leakage & $10(63)$ \\
- Yes & $6(37)$ \\
- No & \\
Purulent leakage & $10(63)$ \\
- Yes & $6(37)$ \\
- No & \\
Superficial SSI & $12(75)$ \\
- Yes & $4(25)$ \\
Clean surgical wound & \\
- Yes & $8(50)$ \\
- No & $8(50)$ \\
\hline
\end{tabular}

Note: SSI=surgical site infection; $C D C=$ centers for disease control 
positive culture with causative microorganisms. There were Pseudomonas aeruginosa in 4 patients (57.1\%), Escheria coli in 1 patient (14.2\%), Staphylococcus aureos in 1 patient $(14.2 \%)$, and in 1 case there was co-infection between $P$. aeruginosa and $S$. aureos. Nine patients did not undergo culture examination.

Relationship between leucocyte count or PCT and SSI is presented in TABLE 4. No significant relationship between leucocyte count and SSI was observed. However, OR analysis showed that patients having abnormal leucocyte had SSI risk of 3.295 times higher than the normal one. In contrast, significant relationship between PCT and SSI was observed. Moreover, OR analysis showed patients having abnormal PCT had SSI risk of 22.000 higher than the normal one.

TABLE 4. Relationship between leucocyte count or PCT and SSI

\begin{tabular}{|c|c|c|c|c|c|c|}
\hline \multirow{2}{*}{\multicolumn{2}{|c|}{ Independent variables }} & \multicolumn{2}{|c|}{ SSI } & \multirow{3}{*}{$\mathrm{p}$} & \multirow{3}{*}{ OR } & \multirow{3}{*}{$95 \% \mathrm{CI}$} \\
\hline & & \multirow{2}{*}{$\begin{array}{c}\text { Yes } \\
\mathrm{Il}(\%)\end{array}$} & \multirow{2}{*}{$\begin{array}{c}\text { No } \\
\mathrm{II}(\%)\end{array}$} & & & \\
\hline & & & & & & \\
\hline \multirow{2}{*}{ Leucocyte count } & Abnormal & $5(55.56)$ & $4(44.44)$ & \multirow{2}{*}{0.105} & \multirow{2}{*}{3.295} & \multirow{2}{*}{$(0.745-14.547)$} \\
\hline & Normal & $11(27.50)$ & $29(72.50)$ & & & \\
\hline \multirow{2}{*}{$\mathrm{PCl}$} & Abnormal & $11(78.57)$ & $3(21.43)$ & \multirow{2}{*}{$(0.00)(0)$} & \multirow{2}{*}{$22.0(0)$} & \multirow{2}{*}{$(4.489-1() 7.813)$} \\
\hline & Normal & $5(14.29)$ & $30(85.71)$ & & & \\
\hline
\end{tabular}

Note: $P C T=$ procalcitonin; $S S I=$ surgical site infection

Comparison of sensitivity and specificity from serum PCT level and leucocyte count to diagnose SSI is presented in TABLE 5. The sensitivity and specificity of leucocyte count were $31.25 \%$ and $87.87 \%$, respectively, whereas, the sensitivity and specificity of serum PCT level were $68.75 \%$ and $90.9 \%$, respectively.

TABLE 5. Leucocyte count result towards SSI case

\begin{tabular}{|c|c|c|c|c|c|c|c|c|}
\hline \multirow{2}{*}{ Variable s } & & \multicolumn{2}{|c|}{ SSI } & \multirow{2}{*}{ Amount } & \multirow{2}{*}{$\begin{array}{c}\text { Sens. } \\
(\%)\end{array}$} & \multirow{2}{*}{$\begin{array}{c}\text { Spec. } \\
(\%)\end{array}$} & \multirow{2}{*}{$\begin{array}{c}\text { PPV } \\
(\%)\end{array}$} & \multirow{2}{*}{$\begin{array}{c}\text { NPV } \\
(\%)\end{array}$} \\
\hline & & Yes & No & & & & & \\
\hline \multirow{3}{*}{ Leucocyte count } & Abnormal & 5 & 4 & 9 & \multirow{3}{*}{31.25} & \multirow{3}{*}{87.87} & \multirow{3}{*}{55.55} & \multirow{3}{*}{72.50} \\
\hline & Normal & 11 & 29 & 40 & & & & \\
\hline & Total & 16 & 33 & 49 & & & & \\
\hline \multirow{3}{*}{ PCT } & Abnormal & 11 & 3 & 14 & \multirow{3}{*}{68.75} & \multirow{3}{*}{90.90} & \multirow{3}{*}{78.57} & \multirow{3}{*}{85.71} \\
\hline & Normal & 5 & 30 & 35 & & & & \\
\hline & Total & 16 & 33 & 49 & & & & \\
\hline
\end{tabular}

Note: $P C T=$ procalcitonin; $S S I=$ surgical site infection; Sens. =sensitivity; Spec. $=$ specificity; $P P V=$ postive predictive value; $N P V=$ negative predictive value 


\section{DISCUSSION}

A study of SSI among adult patients after surgey has been previously conducted in Dr. Sardjito General Hospital. The result showed that the occurrence of SSI was $5.6 \%$ consisting of $3.5 \%$ patients with surgical contamination wound and $2.3 \%$ patients with dirty surgical wound. ${ }^{9}$ Another study conducted in Dr. WZ Yohanes Distric Hospital, Kupang, Nusa Tenggara among patients who underwent caesarean section found that the occurrence of SSI was $16.7 \%$ consisting of $75 \%$ patients with superficial type, $25 \%$ patients with deep incisional type and $25 \%$ patients with reoperated case due to deheciency. ${ }^{10} \mathrm{~A}$ study conducted in Jinnah Postgraduate Medical Center (JPMC), Karachi, Pakistan reported that the SSI was present as much as $7.3 \%(82$ patients) in 1120 patients. As much as $65.9 \%$ of them came from an emergency procedure while the rest $34.1 \%$ came from an elective procedure. According to the surgical wound type, this research reported that there was $1.5 \%$ case of SSI of clean surgical wound, $2.5 \%$ of clean surgical contamination wound, $6.5 \%$ of surgical contamination wound, and $21.4 \%$ of dirty surgical wound. According to the age, SSI most often occurred in the group of 41-60 years old $(75 \%){ }^{11}$

The main causative microorganism of SSI found in this study was $P$. aeruginosa followed by $E$. coli and $S$. aureus. These findings were not different with the previous study conducted in Dr. Sardjito General Hospital reporting that $P$. aeruginosa was the most common cause of SSI accounted for $33.3 \%$ of cases. ${ }^{9}$ Furthermore, $P$. aeruginosa was reported as the common pathogen found in both inpatient and outpatient installation at the hospital, while $P$. aeruginosa and $S$. negative coagulase were reported as the most common pathogen found in the surgical ward and ICU of the hospital. ${ }^{12}$
A multi center study conducted in Thailand reported that the three most common pathogens isolated were E. coli, S. aureus, and $P$. aeruginosa, with $15.3 \%, 8.5 \%$, and $6.8 \%$ cases of infection, respectively. ${ }^{13}$ The variables associated with the risk of SSI were duration of antibiotic prophylaxis, age, elevated American Association of Anaesthetists (ASA) score, prolonged preoperative hospital stay, duration of operation, emergency surgery, and sex. ${ }^{14-16}$

Bivariate analysis between leucocyte count and SSI showed that leucocyte count had no significant relationship with SSI. An abnormal leucocyte count had the possibility of 3.295 times higher than the normal one. However, it was not statistically significant $(\mathrm{OR}=3.295$; 95\% CI=0.745-14.574; $\mathrm{p}=0.105)$. In contrast, serum PCT level had a significant relationship with SSI. An abnormal serum PCT level had the possibility of 22 times higher than the normal one $(\mathrm{OR}=22.000 ; 95 \% \mathrm{CI}=4.489-107.813 ; \mathrm{p}=$ $0.000)$. It was demonstrated that serum PCT level could be a better predictor of SSI compared to leucocyte count. This result was consistent with previous study which also reported that serum PCT level was a better predictor of SSI. ${ }^{13}$ Another study reported that serum PCT level could be used as an infection marker in a febris patient who underwent orthopedic surgery. Moreover, serum PCT level was proclaimed as a significant predictor for postoperative infection. ${ }^{17,18}$

Diagnostic test showed that the sensitivity and specificity of serum PCT level in detecting SSI was higher than those of leucocyte count in this study. This result is in line with previous studies reported by some authors. Study conducted in Tunisia on 100 patients who underwent elective procedure of cardiopulmonary bypass reported that serum PCT level was better than leucocyte count as the biomarker of a bacterial infection after surgery. ${ }^{19}$ 
Moreover, a systemic review concluded that serum PCT level is important in identifying patients with infectious complications after cardiac surgery. The serum PCT level is useful in differentiating acute graft rejection after heart and/or lung transplantation from bacterial and fungal infections. ${ }^{20}$ Another study also reported that serum PCT level is more accurate to diagnosis of bacterial infection due to high sensitivity and specificity. ${ }^{21}$ Furthermore, the serum PCT level can be used to support clinical and microbiological examination to decide whether the fever post orthopedic surgery is caused by infection or non-infection factors. Serum PCT level is also significantly higher in infected patients on day 0,1 , and 3 of fever while it does not happen with the leucocyte count. This finding underlines the potential function of serum PCT level as a predictor of infection after surgery on day 0,1 , and 3 of fever. ${ }^{18}$ Serum PCT level also had diagnostic value to diagnose infection and bacteremia. Serum PCT level showed a better predictor than leucocyte count to detect an infection caused by $S$. negative-coagulase growth. ${ }^{22}$

Although many studies reported that serum PCT level had a high predictive value in detecting infection after surgery, ${ }^{18-22}$ however, a study conducted in patients who underwent elective spinal urgery gave different result, as serum PCT level in general remained at $<0.25$ $\mathrm{ng} / \mathrm{mL}$ during the postoperative course. Moreover, serum PCT level did not correlate with age, sex, DM, hypertension, BMI, operation time, operation site, or use of instrumentation. ${ }^{23}$

\section{CONCLUSION}

Serum PCT level is more sensitive and specific than leucocyte count to diagnose SSI in patients who underwent major surgery. The sensitivity and specificity of serum PCT level are $68.75 \%$ and $90.9 \%$, respectively, whereas the sensitivity and specificity for the leucocyte count are $31.25 \%$ and $87.87 \%$, respectively.

\section{ACKNOWLEDGEMENTS}

Authors would like to thank all patients who have participated in this study.

\section{REFERENCES}

1. Madoff LC \& Kasper DL. Introduction to infectious diseases: host-pathogen interactions. In: Fauci AS, Braunwald E, Kasper DL, Hauser SL, Longo DL, Jameson JL, Loscalzo J editors. Horrison's principles of internal medicine $17^{\text {th }} \mathrm{ed}$. New York: McGraw-Hill, 2008.

2. Ducel G, Fabry J, Nicolle L editors. Prevention of hospital-acquired infections: a practical guide, $2^{\text {nd }}$ ed. Geneva: World Health Organization, 2002.

3. Klevens RM, Edwards JR, Richards CL Jr, Horan TC, Gaynes RP, Pollock DA et al. Estimating health care-associated infections and deaths in U.S. hospitals, 2002. Public Health Rep 2007; 122(2): 160-6.

4. NCC-WCH. Surgical site infection prevention and treatment of surgical site infection, clinical guideline. National Collaborating Centre for Women's and Children's Health and clinical excellence. London: RCOG Press, 2008.

5. Bratzler DW, Hunt DR. The surgical infection prevention and surgical care improvement projects: national initiatives to improve outcomes for patients having surgery. Clin Infect Dis 2006;43(3):322-30.

6. Hatherill M, Tibby SM, Sykes K, Turner C, Murdoch IA. Diagnostic markers of infection: comparison of procalcitonin with C-reactive protein and leucocyte count. Arch Dis Child 1999; 81(5):417-21.

7. Meisner M. Biomarkers of sepsis: clinically useful? Curr Opin Crit Care 2005; 11(5):473-80.

8. Jebali MA, Hausfater P, Abbes Z, Aouni Z, Riou B, Ferjani M. Assessment of the accuracy of procalcitonin to diagnose postoperative infection after cardiac surgery. Anesthesiology 2007; 107(2):232-8.

9. Singgih H. Faktor resiko infeksi luka operasi pada pasien pasca bedah dewasa di Unit Bedah RSUP DR. Sardjito Yogyakarta [Tesis]. Yogyakarta: Universitas Gadjah Mada, 2002. 
10. Rasvitri. Hubungan antara indikasi, pemrakarsa dan prosedur Caesarean section dengan terjadinya infeksi luka operasi di RSUD Prof. DR.WZ. Johannes Kupang [Tesis]. Yogyakarta: Universitas Gadjah Mada, 2009.

11. Bibi S, Channa GA, Siddiqui TR, Ahmed W. Frequency and risk factors of surgical site infections in general surgery ward of a tertiary care hospital of Karachi, Pakistan. J Infect Control 2011; v7:i3 doi: 10.3396/ijic.

12. Anonim. Pola kuman di RSUP DR Sardjito [Laporan Penelitian]. Yogyakarta: Bagian Patologi Klinik RSUP DR. Sardjito, 2011.

13. Kasatpibal N, Jamulitrat S, Chongsuvivatwong V. Standardized incidence rates of surgical site infection: a multicenter study in Thailand. Am J Infect Control 2005; 33(10):587-94.

14. Razavi SM, Ibrahimpoor M, Sabouri KA, Jafarian A. Abdominal surgical site infections: incidence and risk factors at an Iranian teaching hospital. BMC Surg 2005; 5:2. Doi:10.1186/1471-2482$5-2$

15. Hernandez K, Ramos E, Seas C, Henostroza G, Gotuzzo E. Incidence of and risk factors for surgical site infections in a Peruvian hospital. Infect Control Hosp Epidemiol 2005; 26(5): 4737.

16. Kaye KS, Schmit K, Pieper C, Sloane R, Caughlan KF, Sexton DJ, Sch-mader KE. The effect of increasing age on the risk of surgical site infection. J Infect Dis 2005; 191(7):1056-62.
17. Meisner M. Biomarkers of sepsis: clinically useful? Curr Opin Crit Care 2005; 11(5):473-80.

18. Hunziker S, Hugle T, Schuchardt K, Groeschl I, Schuetz P, Mueller B, et al. The value of serum procalcitonin level for differentiation of infectious from noninfectious causes of fever after orthopaedic surgery. J Bone Joint Surg Am 2010; 92(1):138-48.

19. Jebali MA, Hausfater P, Abbes Z, Aouni Z, Riou B, Ferjani M. Assessment of the accuracy of procalcitonin to diagnose postoperative infection after cardiac surgery. Anesthesiology 2007; 107(2):232-8.

20. Sponholz C, Sakr Y, Reinhart K, Brunkhorst F. Diagnostic value and prognostic implications of serum procalcitonin after cardiac surgery: a systematic review of the literature. Crit Care 2006; 10(5):R145.

21. Simon L, Gauvin F, Amre DK, Saint-Louis P, Lacroix J. Serum procalcitonin and C-reactive protein levels as markers of bacterial infection: a systemic review and meta-analysis. Clin Infect Dis 2004; 39(2):206-17.

22. Schuetz P, Albrich W, Mueller B. Procalcitonin for diagnosis of infection and guide to antibiotic decisions: past, present and future. BMC Med 2011; 22(9):107. Doi: 10.1186/1741-7015-9107

23. Chung YG, Won YS, Kwon YJ, Shin HC, Choi CS, Yeom JS. Comparison of serum CRP and procalcitonin in patients after spine surgery. $\mathrm{J}$ Korean Neurosurg Soc 2011; 49:43-8. 